\title{
THE ROLE OF SHARIAH LAW IN ISLAMIC FINANCIAL CONTRACTS IN THE UK AND THE US: A COMPARATIVE ANALYSIS
}

\author{
Apnizan Abdullah* \\ Shahrul Mizan Ismail ** \\ Halila Faiza Zainal Abidin***
}

\begin{abstract}
The adoption of the doctrine of secularism in the United States of America (USA) and the United Kingdom (UK) is clear. Secularism separates human activities in the public sphere from religion. In Western countries, the development of Islamic finance, which stands on the principles of Shariah, could be impeded due to this doctrine. This is because, in Islam, religion is part and parcel of human life. Unlike the US, the UK has made certain efforts to accommodate Islamic finance needs by amending its regulatory structure. Adequate regulatory set ups for Islamic finance in both countries are very crucial, particularly in the UK, since its government aims to promote London as the hub for Islamic finance in Europe. Therefore, in view of the importance of these two giant financial jurisdictions, this study aims to provide a comparative legal analysis of the position of Shariah in Islamic financial contracts in the UK and the US. In particular, this study highlights the legal and judicial treatments made by the courts in both countries pertaining to the subject matter. This study concludes by highlighting the present position of the subject matter.
\end{abstract}

Keywords: Shariah, governing law, secular countries, Islamic banking and finance.

\section{Introduction}

The revival of Islamic finance in the modern era could be credited to the establishment of the MitGharm Local Saving Bank of Egypt in 1963. This institution was based on the principle of Mudharabah and was intended to provide interest-free savings for farmers in its locality. The independence of many Muslim countries in the 1960s and 1970s contributed to the accelerated growth of Islamic financial institutions of this sort. Indeed, the world witnessed a mushrooming of Islamic financial institutions in 1970s, particularly in the Middle East and including the Dubai Islamic Bank in 1975, the Faisal Islamic Bank of Egypt in 
1977, the Bahrain Islamic Bank in 1979 and many more. Subsequently, Islamic banking and finance started to develop in other countries, such as Pakistan in 1977, Iran in 1979 and Malaysia in 1983. ${ }^{1}$ More recently, the growth of Islamic finance has even extended to Western countries such as the United Kingdom, the United States of America, and France.

Overall, Islamic finance is currently present in 70 countries. The wide participation of financial institutions in both Muslim majority countries and non-traditional domiciles has led to the accumulation of global Islamic finance assets totalling more than USD2 trillion as at end-2014. This figure is projected at nearly USD3.5 trillion by 2018. Current Islamic financial activities comprise mainly Islamic banking, sukuk issuance, wealth management funds and takaful. ${ }^{2}$

Although steps have been taken by both the UK and the US governments to increase their participation in the Islamic finance sphere, the UK has been more rigorous efforts to accommodate Islamic finance within a secular system than the US. As legal infrastructure is the backbone of the operation of Islamic finance, with Shariah compliance being a key feature, an analysis of the position of Shariah in Islamic financial contracts in secular jurisdictions is worth considering.

This article is structured as follows: Section 1 covers a brief introduction while Section 2 delineates an overview of Islamic finance operations in the analysed countries, namely the UK and the US. The following Section 3 analyses the position of Shariah in Islamic financial contracts of both jurisdictions and with reference to the decided cases therein. Finally, Section 4 concludes the discussion with selected policy recommendations.

\section{Islamic Finance in the UK}

Historically, the existence of Shariah compliant products in the UK financial market can be traced to the 1980s, even though its serious development only began in early 2002. At its inception, the UK's Islamic financial products were introduced and subscribed to by Middle Eastern institutions and investors for the wholesale UK financial market. In 1982, Dar Al-Mal-Al-Islami (DMI), based in Geneva, was allowed by the UK government to open an office in London and to mobilise investment funds for Luxembourg Investment Company. Such permission was also granted to Takaful UK Limited, a subsidiary of DMI, which began to offer Muslims residing in the UK access to the Islamic investment opportunities provided by Takaful S.A. in Luxembourg. In the same year, AlBaraka Bank was allowed by the Bank of England to offer Islamic mortgages in the UK. However, it only officially operated two branches in London in 1988 and 1989 and one in Birmingham in 1991. Unfortunately it ceased this offering in 1993 due to some unresolved technicalities but still continued as an investment 
company. ${ }^{3}$ Prior to the 1990 's, none of the Islamic products on offer in the UK were developed or introduced to cater for Muslim retail market needs, such as house financing, vehicles financing etc. From the 1990s onwards, however, a number of investment banks offered bespoke Shariah compliant products to their Middle Eastern clients, mostly in the areas of trade financing, leasing and project finance. ${ }^{4}$

The treatment given to these products was similar to their conventional counterparts, which made them less competitive. Moreover, financial protection for consumers could not be made available under the UK financial services compensation scheme. ${ }^{5}$ Successful efforts at offering retail Islamic products only materialised in 1997, when the United Bank of Kuwait (later known as Al-Ahli United Bank) came into operation, introducing a house purchase scheme under the murabahah contract followed by Ijarah-based mortgages in $1999 .{ }^{6}$

A speech delivered by Lord Edward George, the then Governor of the Bank of England, in September 1995 at a conference organised by the Islamic Foundation had a huge impact on the development of Islamic finance in the UK. He clearly recognised the promising potential of Islamic banking and finance in the Muslim world and its emergence in Western jurisdictions. He pointed out that Western supervisors ought to understand its operation. Another remarkable milestone was the setting up in 2001 of a high-level working group, chaired by Lord George and with representatives from the City, government, the Muslim community and the Financial Services Authority (FSA). ${ }^{7}$ In a speech in March 2003 at the Islamic Home Finance Seminar, London, Lord George highlighted the outcome of the working group, which had essentially focused on the obstacles faced by Islamic mortgages, such as double taxation of stamp duty, high regulatory capital charges on Ijarah-based mortgages, the disadvantages of Islamic mortgages under the various public sector home ownership schemes, and the housing cost element of Income Support or income-based Jobseekers Allowances. ${ }^{8}$

A positive reaction towards Islamic finance was also forthcoming from Sir Howard Davies during his tenure as the Chairman of the Financial Services Authority (FSA), established in 1997. In his speech at a conference on Islamic Banking and Finance in Bahrain in September 2003, he made a clear indication of the UK's openess to the idea of having an Islamic bank in the UK when saying that "Islamic finance is good for Muslim consumers, good for innovation and diversity in our markets and good for London as an international financial centre."

Eventually, the UK government enacted the Finance Acts 2005 and 2006 respectively to remove the double taxation regime on Islamic mortgages as contained in the Finance Act 2003. This measure has provided same tax competitiveness. In addition, the Finance Act 2007 was introduced to provide a 
taxation landscape for Sukuk. With these new legal adjustments, the Islamic Bank of Britain was authorised to operate in 2004, followed by the European Islamic Investment Bank in 2006 and The Bank of London in July 2007. ${ }^{10}$

The former UK Prime Minister, David Cameron, made a commitment on 29 October 2013, when delivering his speech at the $9^{\text {th }}$ World Islamic Economics Forum, as to the UK's readiness to accommodate the necessary infrastructures for the Islamic financial sector. ${ }^{11}$

The UK's first sovereign Sukuk issued in June 2014 marked another milestone, proving the UK's commitment widening the Islamic finance agenda. ${ }^{12}$ The availability of the Shariah index, namely FTSE Shariah Global Indexes and Russell Islamic Global Indexes, at the London Stock Exchange allows investors to participate in Shariah-compliant investment products that meet the requirements of Islamic investors globally. ${ }^{13}$ With USD4.5 billion of assets for over 20-UK based institutions offering Islamic financial services, the City expects the market to reach USD3 trillion by $2018 .^{14}$

\section{Islamic Finance in the US}

It is undeniable that the Islamic banking sector has gained a foothold in the United States, with a number of non-bank Islamic financial service entities presently in operation. Islamic finance in the United States of America (the US) actually started in 1987 by virtue of the Islamic financing products offered by LARIBA Bank. This inception of Islamic finance started due to the increasing number of Muslim immigrants to the US. ${ }^{15}$ In 1997, the United Bank of Kuwait began offering retail Islamic mortgages in the US, operating as a Federal branch under the National Bank Act. It also applied to the Office of the Comptroller of Currency (OCC) for guidance on a Sharia-compliant Ijarah home financing product called Al-Manzil. ${ }^{16}$

This pioneering regulatory interpretation obtained by the United Bank of Kuwait opened the door for scalable funding for Islamic finance in America and the development of securitisation, including participation by governmentsponsored entities. ${ }^{17}$ Regulation on murabaha products was also issued by the OCC in 1999 to allow purchase of residential property, and financing for real estate construction, commercial inventory, and acquisition of commercial equipment. ${ }^{18}$ Since then, foreign-based multinationals, such as GE, Exxon, and Royal Dutch Shell, have utilised Islamic financing. In 1999, there were at least three Islamic leasing companies operating in the US. In 2006, there were nine Islamic financial products providers in the US. ${ }^{19}$

Although the growth of Islamic financial activities in the US seems to be less active than the UK, some remarkable milestones have taken place recently. Since the US's wealth management funds possess a high reputation globally, 
retirement funds from all over the world are invested in US-domiciled funds. As of December 2014, there were eight Islamic funds operating in the US, with total assets under management of USD 3.9 million. As far as corporate financing is concerned, US-based sukuk, namely GE Capital Ijarah Sukuk, launched in 2009, Goldman Sachs Wakalah Sukuk and the International Finance Facility for Immunisation (IFFIM) Murabahah Sukuk, issued in September and November 2014 respectively, reflect the potential dynamism of the US financial market for Islamic finance. The current Muslim population in the US stands at under 1\% or around 2.6 million people. However, this figure is forecasted to increase to 6.2 million people by 2030. Thus, with such a large number of Muslims in the country, there is a huge potential for consumer banking services. ${ }^{20}$

Currently, banking regulations in the US are largely market-driven in nature. As far as Islamic finance products and services are concerned, the regulators, namely at the OCC, Federal Deposit Insurance Corporation (FDIC), the Federal Reserve, and state regulatory bodies, develop their decisions on a case-by-case basis when reference or application is made by banks or companies seeking to offer Islamic products. The application of mudharabah, for instance, seems to be uncertain since some have argued that it should be classified as an investment while some claim it is a deposit product.

In a nutshell, there is no specific law accommodating the development of Islamic finance in the US. As mentioned, the burden is imposed on the institutions seeking approval and guidance from the regulators to show how their Islamic products function, the equivalent products already in the market and the permissibility of those products under the financial regulations. ${ }^{21}$ Indeed, there is no commitment made by the US government towards providing necessary adjustments for Islamic finance operation. Hence, the position of Shariah in Islamic financial contracts in the US would be different from in the UK.

\section{Position of Shariah in Islamic Financial Contracts in the UK and the US}

One important step taken by the UK government towards accommodating Islamic finance has been the legal adjustments made regarding the position of Shariah in Islamic financial contracts. This position creates enforceability in the court as well as in arbitration proceedings. Historically, in 2004, the English court refused to accept the application of Shariah in an Islamic financial contract, as remarked in the case of Shamil Bank of Bahrain EC v Beximco Pharmaceuticals Ltd and others [2004] 4 All ER 1072. This seminal decision caused ripples amongst Islamic finance players all over the globe. Since then, many have been concerned about the enforceability of Islamic financial transactions in disputes adjudicated by the English court. 
In this case, the Court of Appeal was obliged to determine the enforceability of the governing law clause in the contract that had made reference to Shariah. In 1995, the bank had agreed to provide its customers with a working capital facility based on the murabahah principle. The murabahah agreement contained the following governing law clause:

"Subject to the principles of the Glorious Shariah, this Agreement shall be governed by and construed in accordance with the laws of England"

When the customers defaulted under the murabahah agreement, the bank terminated the facility and brought the matter for the court's adjudication. The vagueness of the governing law clause was utilised by the customers as a basis for escaping any liability and contractual obligation under the contract. In this case, the court was called to decide on the question of whether, based on the true construction of the governing law clause, the murabahah agreements were enforceable or otherwise. The customers argued that the agreements were only valid and enforceable if they were in accordance both with principles of Shariah and English law. They further claimed that the act of subjecting the contract to Shariah principles while choosing English law as the governing law was an act of making compliance with the Shariah precedent to the enforceability of the contract according to English law. They asserted that the murabahah agreement was not made in compliance with Shariah principles, and hence was not enforceable in the English court.

It was a common ground between the counsels of both sides that there could not be two governing laws in respect of the agreement. The court was also in agreement with them on this point. In the construction of the agreements, the court applied article 3(1) of the Rome Convention, applicable in England by virtue of Section 2(1) of the Contracts (Applicable Law) Act 1990, which provided "A contract shall be governed by the law chosen by the parties." The court held that that the phrase "the law" in this provision refers to the choice of the law of a country and not a non-national system of law, such as the lex mercatoria, general principles of law, or the Shariah. This was based on article 1(1) of the Rome Convention which provided "The rules of this convention shall apply to contractual obligations in any situation involving a choice of laws of different countries" as well as the reference to a choice of "foreign law' in article 3(3). Consequently, the court rejected the application of Shariah as the governing law of the contract and came to the conclusion that the applicable law was English law. ${ }^{22}$ The Court ruled that:

It was common ground by concession that there could not be two separate systems governing the contract... Yet by contending that Shariah law and not English law would determine the enforceability 
of the agreement, the defendant in substance contending that the agreements were governed both by English and Shariah law. The judge declined to construe the wording of the clause as a choice of Shariah law as the governing law for the following reasons. First, Article 3 (1) of the Rome Convention (1980) contemplates that a contract shall be governed by the law chosen by the parties and Article 1(1) of the convention makes it clear that the reference to the parties' choice of the law to govern a contract is a reference to the law of a country. There is no provision for the choice or application of a non-national system of law such as Shariah law...

It is indeed trite that a foreign law may be incorporated as terms of a contract provided that a specific code or set of rules for the foreign law is identified. This position was clearly stated in the case of NeaAgrex SA v Baltic Shipping Co Ltd [1976] 1 QB 933. In that case, the court decided that under the purview of English law, only the recognised law of a country could be incorporated as the governing law of a contract or part of a contract. Other systems of law could not be applied, as clearly mentioned in the case of Musawi $v$ R.E. International [2008] 1 All ER (Comm) 607 as follows:

... at common law the proper law of a contract had to be either English law or the law of another country, and the courts would not apply any other system to a contract. Although I am not aware of any decision to this effect...

Nonetheless, this position changed in 2008 when Rome I Regulation [Regulation (EC) No. 593/2008 of the European Parliament and of the Council on the Law Applicable to Contractual Obligations] dated 17 June 2008 replaced the Rome Convention 1980 in the UK and other EU countries. The UK adopted this regulation on 17 January 2009. Rome I Regulation gave new hope to the further development of Islamic finance in the UK. Article 1 of the Rome I Regulation specifies that:

The rules of this Convention shall apply to contractual obligations in any situation involving a choice between the laws of different countries... This Regulation shall apply, in situations involving a conflict of laws, to contractual obligations in civil and commercial matters.

Further, Preamble 13 of the Rome 1 Regulation states that:

This Regulation does not preclude parties from incorporating by reference into their contract a non-State body of law or an international convention. 
This is a significant development in the UK pertaining to the position of Shariah in a contract. With the coming into force of the Rome I Regulation, there is a greater opportunity for the Islamic finance sector to apply Shariah law in its contracts since this regulation allows the application of non-national laws by contracting parties. Should there be any dispute arising from a contract based on Shariah principles, the court would enforce it accordingly.

In contrast, as far as arbitration in the UK is concerned, the enforceability of a non-national law has been possible even before the coming into force of the Rome I Regulation. Arbitration in the UK is governed by the English Arbitration Act 1996. Section 46(1) of the Act provides that:

The arbitral tribunal shall decide the dispute - (a) in accordance with the law chosen by the parties as applicable to the substance of the dispute or;

(b) if the parties so agree, in accordance with such other considerations as agreed by them or determined by the tribunal.

In Musawi v RE International, the English High Court held that section 46(1) (a) of the English Arbitration Act 1996 makes it clear that the applicable law must be the law of a country. But for the application of section 46(1)(b) of the same Act, the Court relied on Dicey, Morris and Collins on the Conflict of Laws (14 ${ }^{\text {th }}$ ed.) which states that the provision "allows the parties the freedom to apply a set of rules or principles which do not in themselves constitute a legal system. Such a choice may thus include a non-national set of legal principles (such as the 1994 UNIDROIT Principles of International Commercial Contracts) or, more broadly, general principles of commercial law or the lex mercatoria."

In that case, the parties agreed to refer their dispute to arbitration by an Ayatollah in accordance with Shia Shariah law. The High Court held that this was an agreement that the parties were entitled to make under section 46(1)(b) of the Arbitration Act 1996 since the phrase 'such other considerations' in that section applies to religious laws. This position has been confirmed by the Court of Appeal in Halpern v Halpern [2007] 2 All ER (Comm) 330, which concerned the application of Jewish law to a contract.

Therefore, prior to the coming into force of the Rome I Regulation, when parties agreed in their contract to apply a non-national law or principles of law, the enforceability of such law would be very much dependent on their choice of dispute settlement mechanism, namely either through court or by arbitration proceedings. Should the parties choose the court to adjudicate their disputes, non-national law would not be enforced. However, if the parties referred their dispute to arbitration, the matter would be decided based on their choice of governing law, even if it was non-national law. To obtain this legal position, the contracting parties must observe that the Arbitration Act 1996 is applicable only 
where the seat of arbitration is in England and Wales or Northern Ireland. Failure to indicate the seat may result in a decision that the Act does not apply. ${ }^{23}$ It is also arguable that the Arbitration Act 1996 applies when the parties agree that English arbitration law will govern their arbitration proceedings.

In the US, on the other hand, the application of Shariah law has been understood as contradicting the Establishment Clause of the United States Constitution, as argued in the case of Murray v. Geithner, 763 F. Supp. $2 d 860$ (ED Mich. 2011). This government bailout was asserted to be unconstitutional as it was an act of promoting or meddling in a religion in the US, which contradicting the principle of secularism adopted by the country. In this case, the AIG had been involved in providing Takaful products based on Shariah law. Due to this, it was vehemently claimed that the bailout was an act of promoting a religion, hence contradictory to the Establishment Clause of the US Constitution.

As far as the application of Shariah law in any contract, including an Islamic financial contract is concerned, the attitude of the US courts is therefore clear. They only enforce such law when it is part of a recognised national law system agreed by the parties to be the law of the contract. Any non-national legal system cannot therefore be the law of a contract between parties. In Saudi Basic Indus. Corp. v. Mobil Yanbu Petrochem. Co. 866 A.2d 1 (Del. 2005) and National Group for Communications \& Computers v. Lucent Technologies International 331 F. Supp. $2 d 290$ (D.N.J 2004), the court had allowed the enforceability of Saudi law as the governing law of the contracts involved because Saudi law is a recognised national law; it is a Shariah-based law, administered in Saudi Arabia. Thus, the application of Shariah law in court without reference to any country or state will not be enforceable.

The position of Shariah law as the governing law of a contract in an arbitration proceeding in the US is still unclear. Although the US court or arbitrator ought to enforce the choice of law made by the parties, its application is very much dependent on public policy consideration. Private citizens, both Muslims and non-Muslims alike, may enforce the agreements they have made between and amongst each other by filing a case in the appropriate court seeking various remedies. The challenge for Muslims seeking enforcement under binding Islamic arbitration is to demonstrate to the court that it has the legal authority to enforce the Arbitration Award, given the fact that it is based on another system of law outside the US Constitutional framework. ${ }^{24}$

\section{Conclusion and Recommendations}

The enforceability of Shariah law when chosen as the law of any Islamic financial contract varies between the UK and the US. Its enforceability co-relates with the aspiration of the governments concerned towards certain matters concerning 
their jurisdictions. The UK government, for example, has shown its commitment towards accommodating the needs of Islamic finance operation. Consequently, numerous changes have taken place in their financial markets; the laws were adjusted accordingly and government policies made friendly to Islamic finance operations. Even so, due to the infancy of Islamic banking and finance, the legal landscape in the UK must improvise from time to time.

Compliance with Shariah law is mandatory for any Islamic financial contract. When Shariah is used in an Islamic financial contract, it will be enforced accordingly in the UK's court and in arbitration proceeding based on the present legal structure. As discussed, Rome I Regulation now allows the application of Shariah principles. The previous position under the repealed Rome Convention was that Shariah law would only be enforceable if referred to as part of a recognised national law. Shariah law per se (or Shariah principles) were not entertained as a valid choice of governing law in the English court. However, the position in arbitration has been the same since the time of the Rome Convention. This is due to the English Arbitration Act 1996, which allows religious law to be a choice of governing law for any contract. The only requirement is that the contracting parties must specifically identify the seat of arbitration to be either England and Wales or Northern Ireland - or, arguably, provide for the English arbitration law as the law governing their arbitration proceedings.

Islamic finance practitioners in the US are facing difficulties constructing Islamic financial products. Their present products are only those proven to be consistent with the guidelines governing existing conventional products. As Islamic finance relies on Shariah compliance, the construction of the contracts involved must be made in the light of Shariah law and principles. The position of Shariah law in the US is that it will only be enforceable in a US court if it is a national law. Non-national laws will not prevail. Thus, should Shariah be used in an Islamic financial contract, it will only be applied if it is the recognised law of a country (for instance Saudi Arabia or as administered in Malaysia). As far as arbitration is concerned, the position in the US is unclear. The burden to prove its enforceability lies on the parties seeking to enforce it via arbitration.

Since both the UK and the US possess huge potential for the development of Islamic finance, necessary adjustments ought to be made to allow positive growth in both countries. One of the key success factors for the development of Islamic finance in any jurisdiction is the existence of a conducive legal framework that supports the operation and growth of the industry. It is therefore of no surprise that jurisdictions that take immediate steps in adjusting their legal framework for the purpose of Islamic finance have managed to achieve significant growth in the field. ${ }^{25}$ Numerous efforts have been put forward by the UK government to actualise its aspiration to make London the hub of Islamic finance. These efforts 
include providing legal certainty as to the position of Shariah law in court and arbitration proceedings.

Unlike the UK, the US government has not shown a positive commitment towards accommodating Islamic development in the country. This may be attributed to government policy towards the issue. Nevertheless, since the US financial market has enjoyed a positive reputation in the global financial system, especially in wealth management funds, corporate financing, consumer banking and insurance, the US government should take the necessary steps towards accommodating Islamic finance development in the country. Thus, it is recommended that the path taken by the UK government concerning this matter be adopted by the US government too, should they be committed to making Islamic finance prosper in their jurisdiction.

\section{Notes}

* Apnizan Abdullah is Research Fellow at the International Institute of Advanced Islamic Studies (IAIS) Malaysia, Kuala Lumpur. She can be contacted at apnizan@iais.org.my.

** Shahrul Mizan Ismail is Associate Professor at Universiti Kebangsaan Malaysia, Bangi, Selangor. He can be contacted at shahrulmizan@ukm.edu.my.

*** Halila Faiza Zainal Abidin is PhD candidate at Universiti Kebangsaan Malaysia, Bangi, Selangor. She can be contacted at halila79@gmail.com

1. Apnizan Abdullah and Abdullah Abdul Rahman, 'Origin and Development of Islamic Banking and Finance,' in Islamic Banking \& Finance: Principles, Instruments \& Operation, ed. Adnan Trakic and Hanifah Haydar Ali Tajuddin (Ampang: CLJ Publication, 2016), 17.

2. Bank Negara Malaysia, US: Potential Market for Islamic Finance (15 April 2015), 1-3.

3. Ahmed Belouafi \& Abdelkader Chachi, 'Islamic Finance in the United Kingdom: Factors Behind its Development and Growth,' Islamic Economic Studies 22, no. 1 (2014): 48-9.

4. Sharjil Ahmed, 'History of Islamic Finance in the UK,' in UK Excellence in Islamic Finance (London: UK Trade \& Investment, 2013), 10-3.

5. Michael Ainley. Ali Mashayekhi Robert Hicks Arshadur Rahman Ali Ravalia, Islamic Finance in the UK: Regulation and Challenges (London: Financial Services Authority, 2007), 6.

6. See n. 6 , at 49 .

7. See n. 8 , at 8 .

8. See http://www.bankofengland.co.uk/archive/Documents/historicpubsspeeches /2003/speech193.pdf

9. Ibid.

10. Ibid. 
11. For further details, see https://www.gov.uk/government/speeches/worldislamic-economic-forum-prime-ministers-speech (Accessed on: 20 January 2015).

12. See https://www.gov.uk/government/news/government-issues-first-islamic-bond

13. See http://www.lseg.com/sukuk

14. London Stock Exchange, 'Accessing the Global Markets Through London: London Stock Exchange Sukuk', (Accessed on: January, 2017), 23.

15. R.W Toan, 'Cross-Border Ijāra A Case Study in the U.S. Taxation of Islamic Finance.' Paper presented at the Third Harvard University Forum on Islamic Finance: Local Challenges, Global Opportunities Cambridge, Massachusetts. Center for Middle Eastern Studies, Harvard University. (1999):191-7.

16. Victoria Lynn Zyp, Islamic Finance In The United States: Product Development And Regulatory Adoption,' Unpublished MA Thesis, Georgetown University (2009).

17. Thomas, Abdulkader, President and CEO, SHAPE Financial Corporation. Interview by Victoria Lynn Zyp, 29 March 2009. See n. 15, at 10.

18. See n. 15 , at 15 .

19. Chiu, S and Newberger, R, 'Islamic Finance: Meeting Financial Needs with Faith Based Products,' Profitwise News and Views (2006): 8-14.

20. See n. 5, at 5-7.

21. See n. 15, at 19-25.

22. Abdullah Abdul Rahman, 'Shariah as the governing law of Islamic finance contracts in the UK: The impact of Rome I Regulation and the position in arbitration,' Islamic Finance News 11, issue 32, 13, (August 2014): 23 and 24.

23. Ibid.

24. The Center For Security Policy, Shariah In American Courts The Expanding Incursion Of Islamic Law in The U.S. Legal System (Washington: The Center For Security Policy, 2014), 50-1.

25. Mohammad bin Ibrahim, 'Islamic finance and Malaysia's role,' a luncheon address the Deputy Governor of the Central Bank of Malaysia, at the $21^{\text {st }}$ Conference of Presidents of Law Associations in Asia on 'Islamic Finance and Malaysia’s Role,' Kuala Lumpur, 27 July 2010. <http://www.bis.org/review/ r100803f.pdf> 